INHERITING GADAMER 
Not for distribution or resale. For personal use only. 


\section{INHERITING GADAMER}

New Directions in Philosophical Hermeneutics

Edited by Georgia Warnke 
(C) editorial matter and organisation Georgia Warnke, 2016

(C) the chapters their several authors, 2016

$$
\begin{gathered}
\text { Edinburgh University Press Ltd } \\
\text { The Tun - Holyrood Road } \\
\text { I } 2(2 \mathrm{f}) \text { Jackson's Entry } \\
\text { Edinburgh EH8 8PJ } \\
\text { www.euppublishing.com } \\
\text { Typeset in I0.5/I3 Sabon by } \\
\text { Servis Filmsetting Ltd, Stockport, Cheshire, } \\
\text { and printed and bound in Great Britain by } \\
\text { CPI Group (UK) Ltd, Croydon CRo } 4 \mathrm{YY}
\end{gathered}
$$

A CIP record for this book is available from the British Library

$$
\begin{gathered}
\text { ISBN } 978 \circ 748698974 \text { (hardback) } \\
\text { ISBN } 978 \circ 74869898 \text { I (webready PDF) } \\
\text { ISBN } 978 \text { I } 474404884 \text { (epub) }
\end{gathered}
$$

The right of Georgia Warnke to be identified as the editor of this work has been asserted in accordance with the Copyright, Designs and Patents Act I988, and the Copyright and Related Rights Regulations 2003 (SI No. 2498). 